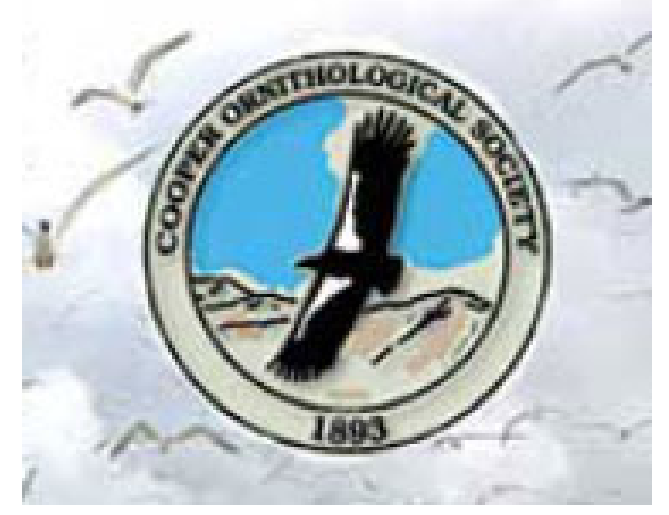

Long-Term Pair Bonds in Harlequin Ducks

Author(s): Cyndi M. Smith, Fred Cooke, Gregory J. Robertson, R. Ian Goudie, W. Sean Boyd Reviewed work(s):

Source: The Condor, Vol. 102, No. 1 (Feb., 2000), pp. 201-205

Published by: University of California Press on behalf of the Cooper Ornithological Society

Stable URL: http://www.jstor.org/stable/1370 424

Accessed: 23/04/2012 16:43

Your use of the JSTOR archive indicates your acceptance of the Terms \& Conditions of Use, available at http://www.jstor.org/page/info/about/policies/terms.jsp

JSTOR is a not-for-profit service that helps scholars, researchers, and students discover, use, and build upon a wide range of content in a trusted digital archive. We use information technology and tools to increase productivity and facilitate new forms of scholarship. For more information about JSTOR, please contact support@ jstor.org. 
Robinson, J. G., AND C. H. Janson. 1986. Capuchins, squirrel monkeys, and atelines: socioecological convergence with Old World primates, p. 69-82. In B. Smuts, D. L. Cheney, P. M. Seyfarth, R. W. Wrangham, and T. T. Struhsaker [EDS.], Primate Societies. Univ. Chicago Press, Chicago.

ScotT, K. 1947. Fairy Bluebird and long-tailed macaque association on Mindanao. Auk 64:130.

Terborgh, J. W. 1983. Five New World primates. Princeton Univ. Press, Princeton, NJ.

ZhANG, S. Y. 1994. Utilisation de l'éspace, stratégies alimentaires et role dans la dissemination des grai- nes du singe capucin Cebus apella (Cebidae, Primates) en Guyane Française. Ph.D. diss., Université Pierre et Marie Curie, Paris.

ZhaNG, S. Y. 1995a. Activity and ranging patterns in relation to fruit utilization by brown capuchins (Cebus apella) in French Guiana. Int. J. Primatol. 16:489-507.

ZHANG, S. Y. 1995b. Sleeping habits of brown capuchins (Cebus apella) in French Guiana. Am. J. Primatol. 36:327-335.

ZHANG, S. Y., AND L. X. WANG. 1995. Comparison of three fruit census methods in French Guiana. J. Tropic. Ecol. 11:281-294.

\title{
LONG-TERM PAIR BONDS IN HARLEQUIN DUCKS ${ }^{1}$
}

\author{
Cyndi M. SMith ${ }^{2}$, Fred COOKe AND Gregory J. RoberTson ${ }^{3}$ \\ Department of Biological Sciences, Simon Fraser University, Burnaby, British Columbia, Canada, V5A 1S6
}

\author{
R. IAN GoudiE ${ }^{4}$ AND W. SEAN BOYD \\ Pacific Wildlife Research Centre, Canadian Wildlife Service, RR 1, 5421 Robertson Rd., Delta, \\ British Columbia, Canada, V4K $3 N 2$
}

\begin{abstract}
We documented the frequency of pair reunion in Harlequin Ducks (Histrionicus histrionicus) on breeding streams in Alberta, and at a molting/wintering area in southwestern British Columbia. As long as their mate is alive, Harlequin Duck pairs reunite on the wintering area and return to the breeding stream together. Pairs reunite even if the female is unsuccessful at breeding the previous season, which suggests that reuniting with the same mate year after year is important. Some males that have lost their mate and fail to re-pair on the wintering area show fidelity to their former breeding site.
\end{abstract}

Key words: breeding site fidelity, Harlequin Duck, Histrionicus histrionicus, mate fidelity, pair reunion.

New pair formation in many of the annually monogamous migratory duck species takes place at the nonbreeding area, often months ahead of the breeding season (Bluhm 1988, Rohwer and Anderson 1988). With-

\footnotetext{
${ }^{1}$ Received 7 December 1998. Accepted 17 July 1999.

${ }^{2}$ Second affiliation: Parks Canada, Banff National Park, Banff, Alberta, Canada, TOL 0C0, e-mail: cyndi_smith@pch.gc.ca

${ }^{3}$ Present address: Canadian Wildlife Service, 6 Bruce St., Mount Pearl, Newfoundland, Canada, A1N 4T3.

${ }^{4}$ Present address: Harlequin Conservation Society, Eastern Office, 17 Waterford Bridge Rd., St. John's, Newfoundland, Canada, A1E 1C5.
}

in the sea ducks (Mergini), timing of pairing varies from September in Common Eiders (Somateria mollissima) (Spurr and Milne 1976) to March in Buffleheads (Bucephala albeola) (Erskine 1972). In Harlequin Ducks (Histrionicus histrionicus), pairs detected in a previous winter reunite in the fall and new pair bonds (including those with young females) form in the spring, both events occurring at the wintering area (Gowans et al. 1997, Robertson et al. 1998).

Although it has been assumed that pairs that formed or reunited in the winter continue through to the breeding season, there has only been one incident recorded for a migratory duck species: one pair of Barrow's Goldeneye Bucephala islandica was observed in both locations (Savard 1985).

Given that Harlequin Ducks show long-term pair bonds (Gowans et al. 1997, Robertson et al. 1999), we examine whether: (1) reuniting is the rule rather than the exception, (2) reuniting during the winter results in the pair breeding together in the following summer, (3) pairs reunite even when breeding was unsuccessful, and (4) some males that fail to re-pair in the winter return to their previous breeding area.

The following definitions are used in this paper. A long-term pair bond between a male and a female lasts for two or more breeding seasons, but may be interrupted during the breeding season (Fowler 1995). $R e$ uniting is pairing with the same mate for a second or subsequent season. Mate change refers to pairs that terminate, or fail to reunite for any reason, including death, disappearance, or divorce (Black 1996), followed by re-pairing with a new partner (Rowley 1983). 


\section{METHODS}

\section{STUDY AREA}

Our evidence of long-term pair bonds comes from concurrent studies on a breeding stream and on a molting/ wintering area. The study on the breeding stream was conducted between May and September (1995-1998) on a $53-\mathrm{km}$ stretch of the Bow River between the Town of Banff and the village of Lake Louise, Alberta, Canada, in Banff National Park on the eastern slope of the Rocky Mountains. The wintering study was conducted from July 1994 to March 1999 on a $5.5-\mathrm{km}$ stretch of coastal shoreline that is near the town of White Rock, in southwestern British Columbia. Data for White Rock for July 1994 to May 1997 are from Gowans et al. (1997) and Robertson et al. (1998), but we have extended the data by an additional 22 months.

\section{FIELD METHODS}

On the breeding stream, paired Harlequin Ducks were chased towards a mist net set across the river (Smith 1996). On the molting area, birds were corralled into a drive trap (Robertson et al. 1998). Captured birds were color-banded and subsequently observed through spotting scopes.

At both study sites, as many banded individuals were identified as possible. Intensive surveys were conducted throughout the year at the wintering area, and the probability of resighting an individual was $100 \%$ during the molt (July-September) and in the spring (March-May) if the bird was alive and on the study site (Robertson et al. 1999). Surveys were conducted once or twice a week during May and June at the breeding area, and the resighting probability was $72 \%$ (C. M. Smith, unpubl. data). Opportunistic observations were made at molting and wintering sites at other locations in the Strait of Georgia, British Columbia.

Pairs were identified by their aggression towards rival conspecifics (McKinney 1992), including mate defense by males and inciting by females, close positioning (Afton and Sayler 1982), preferential or exclusive behavior towards one another, and synchronous activities such as diving and swimming (Gowans et al. 1997). On the breeding stream, pairs were assumed to have arrived together, because no birds were first seen alone then later paired.

\section{RESULTS}

\section{FREQUENCY OF PAIR REUNION}

In all cases where both members of a pair returned to the breeding stream in the following summer, they were paired with the same mate (Table 1). In five cases only one member of the pair returned; one of these (a male) returned without a mate.

In all 37 cases where pairs from a previous winter returned (separately) to the wintering area, they subsequently reunited (Table 1 ). The higher percentage of pair reunions observed at the wintering area than at the breeding stream is likely a function of the higher resighting rate and number of surveys at the former (about 100 vs. about 25 , each year).
TABLE 1. The extent of male fidelity in $[n(\%)]$ Harlequin Ducks that returned to the breeding stream or wintering area.

\begin{tabular}{lcc}
\hline \hline \multicolumn{1}{c}{ Pairing status } & $\begin{array}{c}\text { Breeding } \\
\text { stream }\end{array}$ & $\begin{array}{c}\text { Wintering } \\
\text { area }\end{array}$ \\
\hline Pair reunited & $12(60)$ & $37(77)$ \\
Male returned re-paired & $1(5)$ & $3(6)$ \\
Female returned re-paired & $3(15)$ & $1(2)$ \\
Male returned unpaired & $1(5)$ & $6(13)$ \\
Female returned unpaired & 0 & 0 \\
Neither returned & $3(15)$ & $1(2)$ \\
\hline
\end{tabular}

${ }^{\text {a }}$ Each sighting of reunited pairs in subsequent seasons is counted as an independent sighting.

\section{WINTERING PAIRS AT BREEDING AREA}

Six pairs from the Bow River were observed together the following winter in the Strait of Georgia and then returned together to the Bow River in the subsequent breeding season (one pair twice; Table 2). In three cases, pairs were reunited in the winter, but only one member arrived back at the breeding stream, suggesting death of the mate in late winter or during migration. In no case were members of pairs seen alone in the winter, yet reunited in the following breeding season.

\section{REUNITING WHEN UNSUCCESSFUL}

The fact that in all cases when both mates were known to be alive they returned reunited with the same mate strongly suggests that reuniting occurred even if nesting was unsuccessful. In addition, on 25 July 1996, the female from a marked pair on the Bow River was observed feeding for two hours mid-morning with two other adult females on Moraine Lake. On 13 August 1996, the female from another marked pair was observed in the identical situation. Neither female was observed with young. Both females reunited with their mates and returned to the Bow River in 1997. The second pair had definitely reunited on the wintering area, as they were observed together on 18 March 1997, at Hornby Island, British Columbia.

\section{MALE BREEDING SITE FIDELITY}

Males BG, EE, and E5 returned without their mates in the subsequent breeding season (Table 2). Male BG returned alone two seasons in a row. None of these males re-paired on the breeding stream.

\section{DISCUSSION}

Harlequin Ducks arrive paired at breeding streams in Banff National Park during the last week of April and the first two weeks of May (Smith 1998). Shortly after the hens start incubating, the males depart for their molting areas on the Pacific Coast, and most have left by the end of June. Groups of females, probably nonbreeding females and/or failed nesters, have left the breeding streams by the end of August. Successful hens might not return to the coast until October (Robertson 1997). Thus, members of a pair could potentially be separated for 3 to 4 months.

Adult Harlequin Ducks of both sexes show strong 


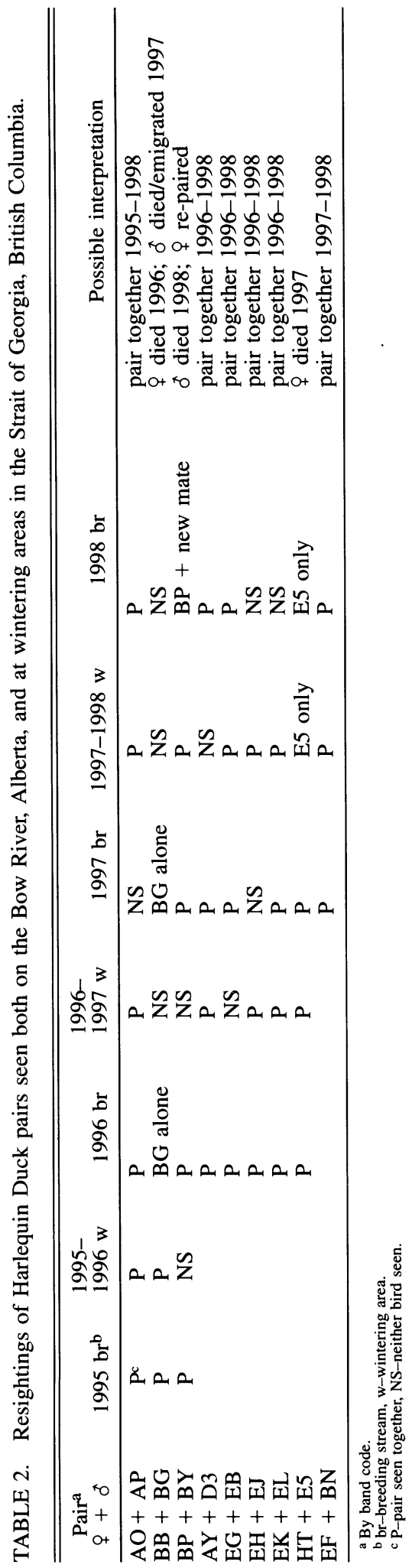

fidelity to molting and wintering areas (Robertson 1997). This increases the likelihood that a female can relocate her mate after months of separation during the incubation and brood-rearing period. The male returns to the wintering site first and waits for his mate to return. Whether winter site fidelity or pair reunion occurs first is unknown. It is possible that philopatry to nonbreeding areas may have evolved in Harlequin Ducks because of the selective advantages of reuniting and improving reproductive output (Robertson 1997). Philopatry to both wintering and breeding sites also is strong in Barrow's Goldeneye and Common Goldeneye (Bucephala clangula) (Savard and Eadie 1989).

Our observations suggest that if both members of a pair are alive, they reunite at the wintering area. Of all the pairs that exhibited mate change, the original mate has never been resighted. Combined with the strong site fidelity, this leads us to assume that such individuals had died. Duck populations are often male-biased (Sargeant et al. 1992), and many males do not find a mate at all. A male-biased sex ratio means that it is easier for females to find a new mate than for males. A male who does not reunite with his previous mate must compete with other single males for females who lost their mates or for young females pairing for the first time. This provides a strong evolutionary reason why males should attempt to reunite with their previous mates (Robertson et al. 1998). Males that do not relocate their previous mate at the usual wintering area may leave to look for a new mate elsewhere.

The female is the only one that knows the outcome of her breeding attempt and has the final decision whether to reunite or not, simply by not returning to the same molting/wintering area where her mate waits. If this were a frequent female tactic, we would expect female breeding site fidelity to be stronger than wintering site fidelity. Our data provide no suggestion of this. Females may benefit from early reuniting by obtaining a mate of known qualities (Savard 1985), and may be protected from harassment by other males (Ashcroft 1976).

Our results show that Harlequin Duck pairs seen on the wintering grounds are the same ones seen on the breeding grounds. Harlequin Duck pairs have previously been recorded as returning to the same breeding stream in subsequent years (Bengtson 1972, Cassirer and Groves 1994). Our results show that the proportion of reunited pairs is actually much higher than previous reports $(60 \%$ vs. $22 \%$ and $33 \%$, respectively), which may be the result of greater survey effort.

Pairs may reunite even if the female was unsuccessful during the breeding season. Early evidence for this was indirect. First, studies on breeding streams show that only a small proportion of females are successful (raising at least one duckling to fledging) even in favorable seasons: $26 \%$ on the Kananaskis River and $40 \%$ on the Bow River in Alberta, in 1997-1998 (Smith 1999a, 1999b), and 38\% (range: 7-55\%) in Montana between 1974 and 1996 (Reichel et al. 1997). Second, females require about 3 months to successfully incubate a clutch and rear a brood. Even if a female nested near the coast, where conditions suitable for breeding start much earlier, it would be unlikely that she would return to the wintering area prior to the 
middle of August. Successful females depart the Cascade Range in coastal Oregon in late August (Bruner 1997). Five marked females from known pairs at White Rock returned before 1 August (suggesting that they were not successful breeders), yet still reunited with their mates.

Our observation of the two females on Moraine Lake suggests that they were either failed nesters or nonbreeders. The sightings were 2-4 weeks after the median hatch date of July 12, and successful females were never observed without their young. Females incubate all through the day, leaving the nest only for one or two hours in the evening to feed (Hunt 1998, Smith 1998). Thus, even when the hen is unsuccessful at raising a brood, the pair reunites, suggesting ther are strong benefits to doing so.

Because annual reproductive success is low and there is a male-biased sex ratio of 1.3 or 1.4 to 1 (C. M. Smith and F. Cooke, unpubl. data), we theorize that by reuniting both males and females are hedging against costs that could be incurred if they had to find a new mate. Such costs include the time and energy of finding a new mate, fighting rivals (males only), the possibility of ending up with a lower quality mate or no mate, and the initial reduced productivity with a new mate (Ens et al. 1996).

Although it is difficult to separate the effects of age and experience, there are a number of components of reproductive success that are correlated with long-term pair bonds: reduced time spent in prelaying behaviors, advanced egg laying date, larger clutch size, and better coordination of parental duties (Fowler 1995). Another potential benefit of reuniting is that one's former partner may possess a suitable breeding site, or useful knowledge of the one previously used (Mock and Fujioka 1990). If a partner does not possess useful attributes, pairs may be expected not to reunite after an unsuccessful breeding attempt.

At least some males unsuccessful in finding a mate at the wintering area appear to return to their previous breeding area, perhaps looking for their previous matt or looking for a new mate. Three males returned to the Bow River in the subsequent breeding season without their mates, and did not pair. Breeding site fidelity in migratory male ducks has been observed in several species and this may be a common, but seldom documented, occurrence because paired males are seldom banded in breeding ground studies.

Further research may show that reuniting may be the rule rather than the exception for the sea ducks, and future work into other members of the Mergini should consider the benefits to pair reunion.

The work in Banff National Park was supported by Parks Canada Highway Services and Aquatic Service, and the Biodiversity Grants Program, Department of Biological Sciences, University of Alberta, through joint efforts of the sportsmen of Alberta and the $\mathrm{Al}$ berta Department of Environmental Protection, Fish and Wildlife Trust Fund. The work at White Rock was generously supported by the British Columbia Waterfowl Society, the Institute for Wetland and Waterfowl Research, and the Wildlife Ecology Chair at Simon Fraser University. The authors thank B. Arquilla, J.
Ashley, P. Clarkson, J. Hardin, D. McIvor, M. McIvor, J. McLeod, N. Martell, R. Torres, J. Whittington, and $\mathrm{K}$. Wright for field assistance. We thank the four anonymous reviewers for their constructive comments on the manuscript.

\section{LITERATURE CITED}

AfTON, A. D., AND R. D. SAYler. 1982. Social courtship and pairbonding of Common Goldeneyes, Bucephala clangula, wintering in Minnesota. Can. Field-Nat. 96:295-300.

AsHCROFT, R. E. 1976. A function of the pair bond in the Common Eider. Wildfowl 27:101-105.

Bengtson, S.-A. 1972. Breeding ecology of the Harlequin Duck Histrionicus histrionicus (L.) in Iceland. Ornis Scand. 3:1-19.

BLACK, J. M. 1996. Introduction: pair bonds and partnerships, p. 3-20. In J. M. Black [ED.], Partnership in birds: the study of monogamy. Oxford Univ. Press, Oxford.

Bluhm, C. K. 1988. Temporal patterns of pair formation and reproduction in annual cycles and associated endocrinology in waterfowl. Current Ornithol. 5:123-185.

BRUNER, H. 1997. Habitat use and productivity of Harlequin Ducks in the central Cascade Range of Oregon. M.Sc. thesis, Oregon State Univ., Corvallis, $O R$.

CAssirer, E. F., AND C. R. Groves. 1994. Ecology of Harlequin Ducks Histrionicus histrionicus in northern Idaho. Unpubl. Tech. Rep., Idaho Dept. Fish and Game, Boise, ID.

Ens, B. J., S. Choudhury, AND J. M. Black. 1996. Mate fidelity and divorce in monogamous birds, p. 344-395. In J. M. Black [ED.], Partnership in birds: the study of monogamy. Oxford Univ. Press, Oxford.

ERskine, A. J. 1972. Buffleheads. Can. Wildl. Monogr. Ser. No. 4.

FowLER, G. S. 1995. Stages of age-related reproductive success in birds: simultaneous effects of age, pairbond duration and reproductive experience. Am. Zool. 35:318-328.

Gowans, B., G. J. Robertson, AND F. CoOKe. 1997. Behaviour and chronology of pair formation by Harlequin Ducks Histrionicus histrionicus. Wildfowl 48:135-146.

Hunt, W. A. 1998. The ecology of Harlequin Ducks Histrionicus histrionicus breeding in Jasper $\mathrm{Na}-$ tional Park, Canada. M.Sc. thesis, Simon Fraser Univ., Burnaby, British Columbia, Canada.

McKinNEY, F. 1992. Courtship, pair formation and signal systems, p. 214-250. In B. D. J. Batt, A. D. Afton, M. G. Anderson, C. D. Ankney, D. H. Johnson, J. A. Kadlec, and G. L. Krapu [EDS.], Ecology and management of breeding waterfowl. Univ. Minnesota Press, Minneapolis, MN.

Mock, D. W., AND M. FuJIOKA. 1990. Monogamy and long-term pair bonding in vertebrates. Trends Ecol. Evol. 5:39-43.

Reichel, J. D., D. L. Genter, AND D. P. HeNDRICKS. 1997. Harlequin Duck research and monitoring in Montana, 1996. Montana Natural Heritage Program, Helena, MT. 
Robertson, G. J. 1997. Pair formation, mating system, and winter philopatry in Harlequin Ducks. Ph.D. diss., Simon Fraser Univ., Burnaby, British Co $\rightarrow$ lumbia, Canada.

Robertson, G. J., F. CoOke, R. I. Goudie, AND W. S. BOYD. 1998. The timing of pair formation in Harlequin Ducks. Condor 100:551-555.

Robertson, G. J., F. COOKE, R. I. Goudie, AND W. S. BOYD. 1999. Within year fidelity of Harlequin Ducks to a moulting and wintering area. In R. I. Goudie, M. Petersen and G. J. Robertson [EDS.], Behaviour and ecology of sea ducks. Can. Wildl. Serv. Occ. Paper 100, Ottawa, Canada.

Rohwer, F. C., AND M. G. ANDERSON. 1988. Femalebiased philopatry, monogamy, and the timing of pair formation in migratory waterfowl. Current Ornithol. 5:187-221.

RowLEY, I. 1983. Re-mating in birds, p. 331-360. In P. Bateson [ED.], Mate choice. Cambridge Univ. Press, Cambridge.

Sargeant, A. B., AND D. G. Raveling. 1992. Mortality during the breeding season, p. 396-422. In B. D. J. Batt, A. D. Afton, M. G. Anderson, C. D Ankney, D. H. Johnson, J. A. Kadlec, and G. L. Krapu [EDS.], Ecology and management of breed- ing waterfowl. Univ. Minnesota Press, Minneapolis, MN.

SAVARD, J-P. L. 1985. Evidence of long-term pair bonds in Barrow's Goldeneye Bucephala islandica. Auk 102:389-391.

SAVARD, J-P. L., AND J. MCA. EAdIE. 1989. Survival and breeding philopatry in Barrow's and Common Goldeneyes. Condor, 91:198-203.

SMITH, C. 1996. Harlequin duck research project Banff National Park: progress report 1996. Unpubl. Tech. Rep. Parks Canada, Banff, Alberta, Canada.

SMITH, C. 1998. Banff National Park Harlequin Duck research project: 1997 progress report. Unpubl. Tech. Rep. Parks Canada, Banff, Alberta, Canada.

SMITH, C. 1999a. Banff National Park Harlequin Duck research project: 1998 progress report. Unpubl. Tech. Rep. Parks Canada, Banff, Alberta, Canada.

SMITH, C. 1999b. Harlequin Duck research in Kananaskis Country, Alberta, in 1998: Kananaskis River and Elbow River. Unpubl. Tech. Rep. Alberta Natural Resources Service, Canmore, Alberta, Canada.

SPURR, E., AND H. MiLnE. 1976. Adaptive significance of autumn pair formation in the Common Eider Somateria mollissima (L.). Ornis Scand. 7:85-89.

\title{
BREEDING BIOLOGY OF GRAY-CROWNED TYRANNULET IN THE MONTE DESERT, ARGENTINA ${ }^{1}$
}

\author{
Eduardo T. MEZQuida ${ }^{2}$ AND Luis Marone \\ Ecodes, UF\&EV, IADIZA, Casilla de Correo 507, 5500 Mendoza, Argentina, \\ e-mail: ricardo.mezquida@adi.uam.es
}

\begin{abstract}
We present information from 75 nests of Gray-crowned Tyrannulet (Serpophaga griseiceps) found in open Prosopis woodlands of the central Monte desert between 1995 and 1997 and compare it with information corresponding to other species of the genus. Breeding occurred from October to January. Nests are small open cups. Both parents participated in nest building, which lasted 4-7 days. In the Prosopis woodland, $98 \%$ of the nests were built in chañar (Geoffroea decorticans), which also is commonly used as a nest plant by $S$. subcristata in east-central Argentina. Mean clutch size did not vary among years nor within the breeding season, and it was similar to that observed in other Serpophaga. Both male and female shared the 13-15 day incubation period. Hatching was asynchronous. Nestling period lasted 13-14 days, during which
\end{abstract}

\footnotetext{
${ }^{1}$ Received 14 December 1998. Accepted 12 August 1999.

${ }^{2}$ Present address: P. Alameda de Osuna $741 \mathrm{C}$, 28042 Madrid, Spain.
}

both parents reared the chicks. Nesting success $(26 \%)$ appeared to be less than that previously reported for Nearctic open-nesters (50-60\%), and Neotropical open-nesters in dry (50\%) and wet tropics (35\%). Egg and nestling predation were the main cause of nest failure.

Key words: Gray-crowned Tyrannulet, nest predation, reproductive biology, Serpophaga griseiceps, South America, Tyrannidae.

Serpophaga is a genus of tyrant flycatchers that comprises five species, found from Costa Rica to Río Negro, Argentina (Fjeldså and Krabbe 1990). These species have a predominantly or entirely gray plumage, usually with a semi-concealed white coronal patch and dark tail. They occur in a wide variety of habitats (Ridgely and Tudor 1994).

Narosky and Yzurieta (1987) considered that three species are found in Argentina: Sooty (S. nigricans), White-crested (S. subcristata), and White-bellied Tyrannulet ( $S$. munda). However, the taxonomic status of 